\title{
Modeling phosphorus distribution under different fertigation strategies in onion (Allium cepa L.) crop
}

\author{
Sanjay T. Satpute ${ }^{*}$ and Man Singh ${ }^{2}$ \\ ${ }^{1}$ Department of Soil and Water Engineering, Punjab Agricultural University, Ludhiana-141 004 ( Punjab), INDIA \\ ${ }^{2}$ Water Technology Centre, Indian Agricultural Research Institute, New Delhi- 110012, INDIA \\ *Corresponding author. E-mail: sanjay4471@gmail.com \\ Received: July 21, 2016; Revised received: December 16, 2016; Accepted: April 13, 2017
}

\begin{abstract}
The understanding of soil and nutrient dynamics under drip fertigation is relevant for crop production as well as water and nutrient management. The aim of this study was to generate information about the distribution of phosphorus $(P)$ under different fertigation strategies for onion production on sandy clay loam soil during 2007-2008 to 2008-2009. The study involved field experiment, laboratory analysis and modeling of $P$ distribution. The phosphorus distribution data in the field were collected, analyzed and used to calibrate and validate the solute transport model HYDRUS-2D for sandy clay loam soil. The performance of HYDRUS-2D was evaluated by comparing its simulated values with the observed values of soil moisture and nutrient concentration. The coefficient of determination $\left(R^{2}\right)$, root mean square error (RMSE) and mean absolute error (MAE) were used as model performance indicators. The range of $R^{2}$ between 0.72-0.99 for water as well as nutrient distribution indicates good correlation between the observed and simulated values. The MAE and RMSE values for water and nutrient distribution were in between 0.0009 to 0.0039 which indicated the accuracy of the model. From these results, it can be concluded that the model is performing well for predicting the $\mathrm{P}$ concentration in the soil as well as the soil moisture distribution for onion crop grown under sandy clay loam. The model was also validated for water and phosphorus distribution with the observed values at the end of the crop season and found to be performing well. The HYDRUS-2D model may be used to carry out simulations for different soil types and with different fertigation and irrigation strategies for developing guidelines.
\end{abstract}

Keywords: HYDRUS-2D, Fertigation strategy, Phosphorus distribution, Onion

\section{INTRODUCTION}

Drip irrigation is often preferred over other irrigation methods because of the former's high water-application efficiency on account of reduced losses, surface evaporation and deep percolation. Improved water use efficiency under drip irrigation by reducing percolation and evaporation losses, provides environmentally safer fertilizer application through irrigation water (Mmolawa and Or, 2000). In countries where the cost of water is very low, such as India, the adoption of drip irrigation has initially been very slow. Recently however, drip irrigation combined with fertigation has been found to benefit farmers because of the very high efficiency of fertilizer use for such irrigation schemes. There is an ample scope for improving the efficiency of fertilizer use through fertigation, if the movement and reactions of fertilizers in the soil are well understood. Fertigation enables the application of soluble fertilizers and other chemicals along with irrigation water, uniformly and more efficiently (Patel and Rajput, 2000; Narda and Chawla, 2002). The dynamics of the water within the soil volume surrounding the emitter represents a prerequisite to design irrigation systems as well as to manage water and nutrients (Akbar et al., 1996; Zur, 1996). Few computer simulation models have the capability to analyze water flow and nutrient transport in multiple spatial dimensions, with the exception of HYDRUS2D (Simunek et al., 1999; Cote et al., 2003) and FUSSIM2 (Heinen, 2001).HYDRUS-2D (Simunek et al., 2006) has been used extensively for evaluating short term nitrogen fertigation strategies and the effects of soil hydraulic properties, soil layering, dripper discharge rates, irrigation frequency, and timing of nutrient applications on wetting patterns and solute distribution (Ajdary et al., 2007; Patel and Rajput, 2008; Hopmans and Bristow, 2002; Doltra and Muñoz, 2010). Gardenas etal. (2005) analyzed four different micro irrigation systems in combination with five different fertigation strategies for various soil types, clearly demonstrating the effects of root distribution and fertigation strategy on the uniformity of water and nutrients around drip lines and their effects on water drainage and associated nitrate leaching by using the HYDRUS-2D.

The soil wetting and solute transport in trickle irrigation 
was analyzed by using HYDRUS-2D model (Cote et al., 2003). Many studies were conducted for water and nitrate distribution under drip fertigation (Ajdary et al., 2007; Rajput and Patel, 2006, Wang et al., 2014) but the information available on phosphorus distribution under drip fertigation is very limited. The nitrogen is more efficiently used when applied with phosphorus, potassium and sulfur. Most of the modeling studies dealing with similar topics are focused on simulations of water flow and nitrate leaching under drip irrigation system, but not the phosphorus distribution, so there is a gap in the understanding how the phosphorus is distributed with drip fertigation.

Keeping in view of the rationale, the present study was conducted to calibrate and validate the HYDRUS-2D for the phosphorus distribution from the onion field under inline drip fertigation system where fertigation was applied through inline drip irrigation system.

\section{MATERIALS AND METHODS}

Location of experimental field: The experiments were conducted in the field of Water Technology Centre, Indian Agricultural Research Institute, New Delhi, India, in 2007-2008 and 2008-2009 to calibrate and validate the HYDRUS-2D for the phosphorus distribution from the onion field under inline drip fertigation. The soil of the experimental site was sandy clay loam and low in organic matter $(0.25 \%)$ with neutral $\mathrm{pH}$ (7.1). These soils have $87.45 \mathrm{~kg} / \mathrm{ha}$ available $\mathrm{N}, 25 \mathrm{~kg} / \mathrm{ha}$ assimilable $\mathrm{P}, 175 \mathrm{~kg} / \mathrm{ha}$ exchangeable $\mathrm{K}$ and $45 \mathrm{~kg} /$ ha sulfur. The depth wise field capacity was varied from 20.91 per cent at $0-15 \mathrm{~cm}$ with gradual increase to $28.86 \%(15-30 \mathrm{~cm})$, $26.33 \%(30-45 \mathrm{~cm})$ and $28.33 \%(45-60 \mathrm{~cm})$ and permanent wilting pointfor similar depth intervals as 6.25 to 6.22 $\%$ and then to 9.86 and $9.94 \%$, respectively. The crop calendar indicating date of sowing to date of harvesting is given in Table 1 and corresponding weather details for both the years are presented in Fig. 1. The weather was cool during the initial stages and warm to hot during the later stages. Rainfall during the two cropping seasons was $176 \mathrm{~mm}$ and $28 \mathrm{~mm}$, respectively. The mean daily evaporation ranged from 2.9 to $5.6 \mathrm{~mm}$ and from 3.5 and $6.6 \mathrm{~mm}$ in the respective cropping seasoni.e. rabi season of 2007-2008 and 2008-2009. The actual mean maximum temperature ranged from $19.5^{\circ} \mathrm{C}$ to $36.5^{\circ} \mathrm{C}$ and $20.5^{\circ} \mathrm{C}$ to $39.0^{\circ} \mathrm{C}$ in the years 2007-2008 and 2008-2009, respectively. The variations in mean minimum temperature from January to May were $5.5^{\circ} \mathrm{C}$ to $23.5^{\circ} \mathrm{C}$ and $7.2^{\circ} \mathrm{C}$ to $24.1^{\circ} \mathrm{C}$ respectively, for the years under consideration.

Treatment and Layout: Two months old seedlings of onion Pusa Madhavi were transplanted in rabi season i.e. in the second week of January during 2008 and 2009 with $15 \mathrm{~cm}$ spacing between rows and $10 \mathrm{~cm}$ between plants. The experiment was laid out in a split plot design having two main treatments $\left(\mathrm{I}_{1}\right.$ and $\left.\mathrm{I}_{2}\right)$ as main plot and four fertigation treatments $\left(\mathrm{F}_{1}, \mathrm{~F}_{2}, \mathrm{~F}_{3}, \mathrm{~F}_{4}\right)$ as subplot keeping the plot size for the each replication as $2.4 \mathrm{~m} \mathrm{X} 5 \mathrm{~m}$. The detailed treatments are given in Table 2.

Irrigation/fertigation scheduling and crop management practices: The inline drip irrigation system with 4 litres per hour (lph) discharge emitter was used under this study. The emitter to emitter distance was kept as $50 \mathrm{~cm}$ and lateral to lateral distance was kept as 60 $\mathrm{cm}$. The growing period of onion was 135 days in both the years of the study from transplanting to harvesting (Table 1). Before transplanting, $25 \mathrm{t} / \mathrm{ha}$ of farm yard manure (FYM) was applied to the field. The chemical fertilizers used in the experiment were urea, ortho-phosphoric acid, potassium chloride and magnesium sulphate as a source of $\mathrm{N}, \mathrm{P}, \mathrm{K}$ and $\mathrm{S}$, respectively. The level of fertilizers adopted in the present study was $120 \mathrm{~kg} \mathrm{~N} \mathrm{ha}^{-1}, 50 \mathrm{~kg} \mathrm{P} \mathrm{ha}^{-1}, 70 \mathrm{~kg} \mathrm{~K}$ $\mathrm{ha}^{-1}$ and $50 \mathrm{~kg} \mathrm{~S} \mathrm{ha}^{-1}$ and it was divided in 12 equal

Table 1. Cultivation operation for two seasons.

\begin{tabular}{lll}
\hline Operation & \multicolumn{2}{c}{ Year } \\
\cline { 2 - 3 } & $\mathbf{2 0 0 7 - 2 0 0 8}$ & $\mathbf{2 0 0 8 - 2 0 0 9}$ \\
\hline Nursery & Nov.10, 2007 & Nov. 10, 2008 \\
Transplanting date & Jan. 09, 2008 & Jan. 09, 2009 \\
Crop Settling & Jan. 09-24, 2008 & Jan. 09-24, 2009 \\
Vegetative development & Jan. 25-Feb. 28, 2008 & Jan. 25-Feb. 28, 2009 \\
Bulbification or Bulb formation stage & Feb. 29-April 18, 2008 & March 01-April 19, 2009 \\
Bulb Maturity stage & April 19-May 23, 2008 & April 20-May 24, 2009 \\
Last irrigation & May 11, 2008 & May 12, 2009 \\
Harvest & May 23, 2008 & May 24, 2009 \\
Length of growing season (From date of transplant- & 135 & 135 \\
ing to Harvesting) (days) & & \\
\hline
\end{tabular}


doses. The fertilizers were injected at eight day interval through the inline drippers which was started 15 days after transplanting and stopped 30 days prior to the end of crop period. The time of application of fertigation injection was different in all four fertigation treatments i.e. fertigation during first half of irrigation duration $\left(\mathrm{F}_{1}\right)$, fertigation throughout irrigation duration $\left(\mathrm{F}_{2}\right)$, fertigation during second half of irrigation duration $\left(\mathrm{F}_{3}\right)$ and fertigation during middle half of irrigation duration $\left(\mathrm{F}_{4}\right)$. Determination of crop water requirement is the primary duty in any irrigation planning. For this, the reference evapotranspiration (ETo) was estimated using the FAO Penman-Monteith equation (Allen et al., 1998) employing previous five year meteorological data. The phenological cycle of onion was divided into four stages from transplanting to harvesting which are considered to be the most relevant from the point of view of their response to irrigation, namely, crop settling ( $1^{\text {st }}-15$ days), vegetative development $\left(2^{\text {nd }}-35\right.$ days $)$, bulbification or bulb formation $\left(3^{\text {rd }}-50\right.$ days $)$ and bulb maturity stage $\left(4^{\text {th }}-35\right.$ days) with a crop coefficients $(\mathrm{Kc})$ as 0.7 for the $1^{\text {st }}$, 0.90 for the $2^{\text {nd }}, 1.05$ for the $3^{\text {rd }}$ and 0.75 for the $4^{\text {th }}$ growth, respectively, given by Allen et al. (1998). The total duration of the crop season was 135 days. The crop water requirements were calculated by multiplying the ETo values with crop coefficients at that particular stage. The crop water requirement and irrigation requirement were calculated by using the $\mathrm{ET}_{\mathrm{c}}$ for both the seasons.

Table 2. Treatment details.

\begin{tabular}{cl}
\hline $\begin{array}{c}\text { Treat- } \\
\text { ment }\end{array}$ & Elaboration \\
\hline $\mathrm{I}$ & Irrigation \\
$\mathrm{F}$ & Fertigation \\
$\mathrm{I}_{1}$ & Two day irrigation interval \\
$\mathrm{I}_{2}$ & Four day irrigation interval \\
$\mathrm{F}_{1}$ & First half fertigation \\
$\mathrm{F}_{2}$ & Throughout fertigation \\
$\mathrm{F}_{3}$ & Second half fertigation \\
$\mathrm{F}_{4}$ & Middle half fertigation \\
$\mathrm{I}_{1} \mathrm{~F}_{1}$ & 2 day irrigation interval with fertigation dur- \\
& ing first half of irrigation duration \\
$\mathrm{I}_{1} \mathrm{~F}_{2}$ & 2 day irrigation interval with fertigation dur- \\
& ing throughout irrigation duration \\
$\mathrm{I}_{1} \mathrm{~F}_{3}$ & 2 day irrigation interval with fertigation dur- \\
& ing second half of irrigation duration \\
$\mathrm{I}_{1} \mathrm{~F}_{4}$ & 2 day irrigation interval with fertigation dur- \\
& ing middle half of irrigation duration \\
$\mathrm{I}_{2} \mathrm{~F}_{1}$ & 4 day irrigation interval with fertigation dur- \\
& ing first half of irrigation duration \\
$\mathrm{I}_{2} \mathrm{~F}_{2}$ & 4 day irrigation interval with fertigation dur- \\
& ing throughout irrigation duration \\
$\mathrm{I}_{2} \mathrm{~F}_{3}$ & $\begin{array}{l}\text { 4 day irrigation interval with fertigation dur- } \\
\text { ing second half of irrigation duration }\end{array}$ \\
$\mathrm{I}_{2} \mathrm{~F}_{4}$ & $\begin{array}{l}\text { 4 day irrigation interval with fertigation dur- } \\
\text { ing middle half of irrigation duration }\end{array}$ \\
&
\end{tabular}

Table 3. Root water uptake parameter of Feddes model.

\begin{tabular}{ccc}
\hline \multirow{2}{*}{ Factors } & \multicolumn{2}{c}{ Onion } \\
\cline { 2 - 3 } & Early growth & Bulb formation stage \\
\hline $\mathrm{P}_{\mathrm{o}}$ & $-10 \mathrm{~cm}$ & $-10 \mathrm{~cm}$ \\
$\mathrm{P}_{\mathrm{opt}}$ & $-25 \mathrm{~cm}$ & $-25 \mathrm{~cm}$ \\
$\mathrm{P}_{2} \mathrm{H}$ & $-450 \mathrm{~cm}$ & $-550 \mathrm{~cm}$ \\
$\mathrm{P}_{2} \mathrm{~L}$ & $-550 \mathrm{~cm}$ & $-650 \mathrm{~cm}$ \\
$\mathrm{P}_{3}$ & $-8000 \mathrm{~cm}$ & $-8000 \mathrm{~cm}$ \\
$\mathrm{R}_{2} \mathrm{H}$ & 0.021 & 0.021 \\
$\mathrm{R}_{2} \mathrm{~L}$ & 0.0042 & 0.0042 \\
\hline
\end{tabular}

Sampling and analysis: Soil samples were collected from different depths viz. 0-15 cm, $15-30 \mathrm{~cm}, 30-45$ $\mathrm{cm}$ and $45-60 \mathrm{~cm}$ and also it was taken at emitter, 15 $\mathrm{cm}$ away from emitter and $22.5 \mathrm{~cm}$ away from emitter and after different time interval (spatial and temporal). In the treatment of two day irrigation interval, soil samples were collected before fertigation, $4 \mathrm{~h}$ after fertigation, $24 \mathrm{~h}, 48 \mathrm{~h}, 52 \mathrm{~h}$ and $72 \mathrm{~h}$ after fertigation and in the treatment of four day irrigation interval, the samples were collected periodically (Before fertigation, 4h, 24 h, 48 h, 72 h, 96 h, $100 \mathrm{~h}$ and $120 \mathrm{~h}$ after fertigation). The tube auger was used for collecting the soil samples from the field and analysed for moisture content and $\mathrm{P}$ concentration using standard procedures.

Water and nutrient transport modelling: In the present study, HYDRUS-2D was selected because it can simulate the effect of the following:

Soil hydraulic properties on water and nutrient movement Discharge rate on the water and nutrient distribution Time dependent flux boundary on water and nutrient distribution

Timing of water and nutrient application on the resultant distribution of water and nutrient distribution within the root zone

Description of hydrus-2d: The modeling of phosphorus leaching from the onion field under drip fertigation was carried out using the computer simulation model, HYDRUS-2D. It simulates three-dimensional axially symmetric water flow; solute transport and root water and nutrient uptake based on finite-element numerical solutions of the flow equations. The model can deal with prescribed head and flux boundaries, controlled by atmospheric conditions, as well as free drainage boundary conditions. The governing flow and transport equations are solved numerically using Galerkin-type linear finite element schemes. The current version 2.0 of HYDRUS includes a Marquardt-Levenberg parameter optimization algorithm for inverse estimation of soil hydraulic and/or solute transport and reaction parameters from measured transient or steady state flow and/or transport data. A detail description of model and related theory is presented in the report documents version 2.0 of HYDRUS (Simunek et al., 1999). 
System geometry: The simulations were done for a soil profile upto a depth of $Z=60 \mathrm{~cm}$ and radius $r=30$ $\mathrm{cm}$, with a drip emitter placed at the surface. The flux radius was taken equal to the wetted radius with corresponding emitter in the centre. Surface area for irrigation without causing ponding was determined from the flux radius and subsequently flux per unit area, resulting from emitter was estimated. Fig. 2 shows the conceptual diagram of simulated area and imposed boundary conditions. No flux was allowed through the lateral boundaries. Bottom boundary was considered as free drainage boundary. Surface boundary was considered as variable flux boundary (up to the radius of $25 \mathrm{~cm}$ ) and atmospheric boundary for remaining $5 \mathrm{~cm}$ radius. The system was conceptually divided into four layersviz. 0-15 cm, $15-30 \mathrm{~cm}, 30-45$ $\mathrm{cm}$ and $45-60 \mathrm{~cm}$ depending on the variability of the soil's physical properties such as texture of soil, hydraulic conductivity, moisture percentage at saturation and residual moisture content in the soil.

Initial and boundary conditions: Initial distribution of the water content in different soil layers within the flow domain was kept as observed in the experimental field. A sample figure showing the initial water content is shown in Fig. 3.

For the purpose of investigating the influence of drip emitter discharge, soil hydraulic properties and frequency of water input on wetting patterns, a time dependent flux boundary condition at the surface in a radius of $25 \mathrm{~cm}$ from emitter position was used. This was done to take into account the irrigation and no irrigation periods and temporal changes in duration of irrigation in the growing period. In the present case, water table was situated far below the domain of interest and therefore free drainage boundary condition at the base of soil profile was considered. On the sides of the soil profile, it was assumed that no flux of water took place and hence no flux boundary condition was chosen, as specified in HYDRUS-2D for impermeable boundaries where the flux is zero perpendicular to the boundary.

\section{Input parameters:}

Soil hydraulic properties: The soil properties considered are water retention $\theta(\mathrm{h})$ and hydraulic conductivity $\mathrm{K}$ (h) functions. In this study, Van Genuchten (1980) analytical model available in HYDRUS-2D was used for the soil hydraulic properties. The model was calibrated for the soil hydraulic properties obtained from field experiment.

Solute transport properties: A range of values of the longitudinal and transverse dispersivities was selected from literature and approximate values were selected after calibration process.

Input for root water uptake: Two root water uptake model of Feddes (1978) and S-shaped model are available in the HYDRUS-2D. The root water uptake model is selected to simulate the root water uptake of onion crop at each point in the root zone according to soil pressure head conditions. $\mathrm{P}_{0 \text { - }}$ the pressure head of which the plant begins to extract water whereas $\mathrm{P}_{0 \mathrm{pt}}$ the pressure head at which plants begin to extract water at maximum possible rate (i.e. potential transpiration rate given in the time variable boundary condition). For a potential transpiration rate of $\mathrm{r} 2 \mathrm{H}$, $\mathrm{P} 2 \mathrm{H}$ is the pressure head at which the plant no longer extracts water at maximum possible rate Root water uptakes ceases at P3 which is usually permanent wilting point. Plant parameters for onion crop at early growth stage and at bulb formation stage are given in Table 3.

Distribution of roots in the root zone in relative term with onion plant is shown in Fig. 4.

Calibration and validation: The model is calibrated for residual water content $\left(\theta_{\mathrm{r}}\right)$, saturated water content $\left(\theta_{\mathrm{s}}\right)$, Alpha $(\alpha)$ and $\mathrm{n}$. The parameters were selected from the run when predicted and observed values are close enough. The model was calibrated for water and nutrient distribution. For nutrient distribution, nutrient transport parameters were taken from literature. After calibration, model was validated with the long term observed data to examine its predictability.

Calibration of the model was done using the values of water content and phosphorus concentration at various points along the line and at different depths as mentioned above, selected in the root zone with respect to the emitter, observed at $4,24,48,52,72$, 100 and 120 hours after fertigation. To check the performance of HYDRUS-2D model, three performance indicators namely, coefficient of determination $\left(\mathrm{R}^{2}\right)$, Root mean square error(RMSE) and mean absolute error (MAE) were used (Willmott, 1981). Root mean square error (RMSE) and mean absolute error (MAE) were calculated using equations as given below. A coefficient of determination of 1.0 represents a perfect prediction while negative and value zero represents a prediction no better than the random variation in the observed data, negative values indicate increasingly poorer predictions (Nash and Sutcliffe, 1970)

$$
\begin{aligned}
& \text { MAE }=\mathrm{N}^{-1} \sum_{\mathrm{i}=1}^{\mathrm{N}}\left|\mathrm{P}_{\mathrm{i}}-\mathrm{O}_{\mathrm{i}}\right| \\
& \text { RMSE }=\sqrt{\sum_{\mathrm{i}=1}^{\mathrm{N}} \frac{\left(\mathrm{P}_{\mathrm{i}}-\mathrm{O}_{\mathrm{i}}\right)^{2}}{\mathrm{~N}}}
\end{aligned}
$$

$\mathrm{i}=1,2,3 \ldots \ldots \ldots \ldots \mathrm{n}$

where, $\mathrm{P}_{\mathrm{i}}=$ Predicted values, $\mathrm{O}_{\mathrm{i}}=$ Observed values $\mathrm{N}=$ Total number of observations; A criterion adopted by Willmott (1981) was considered in evaluating different developed simulation models, the evaluation criteria consisted of:

i) Lower the mean absolute error, model predictions are good with better accuracy

ii) Smaller RMSE value, the better the performance of 
a) $2007-2008$

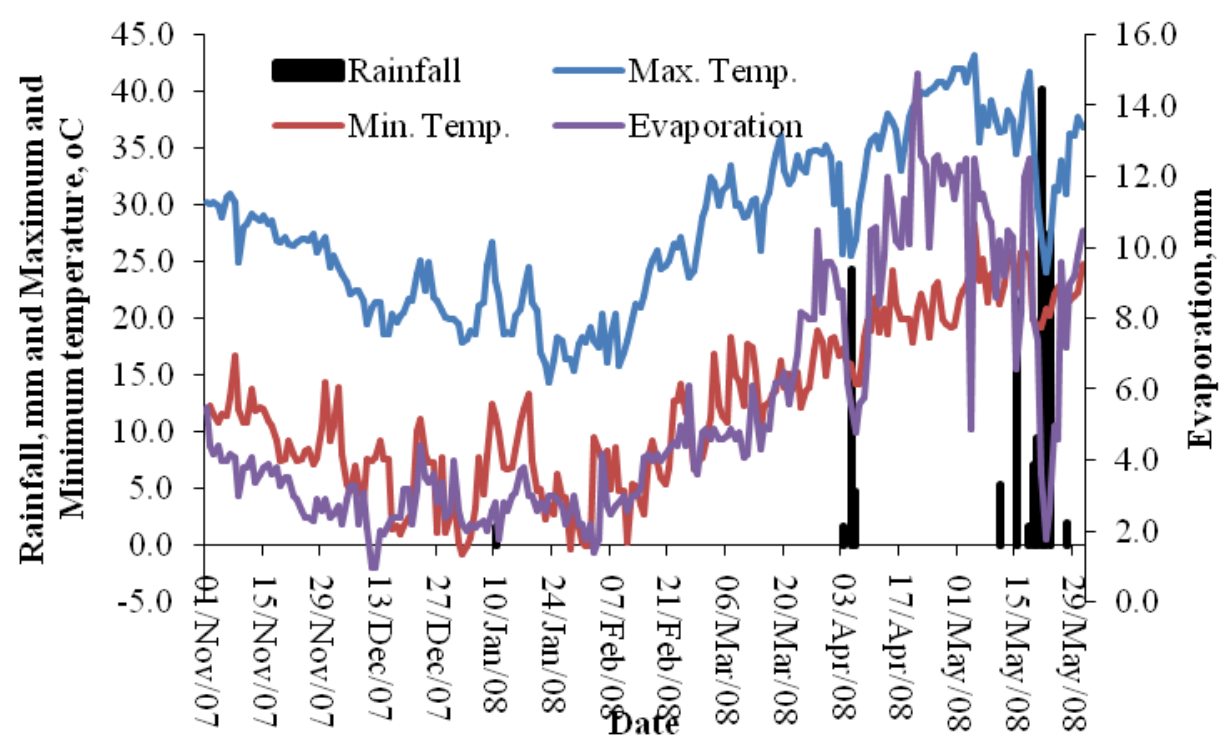

b) $2008-2009$

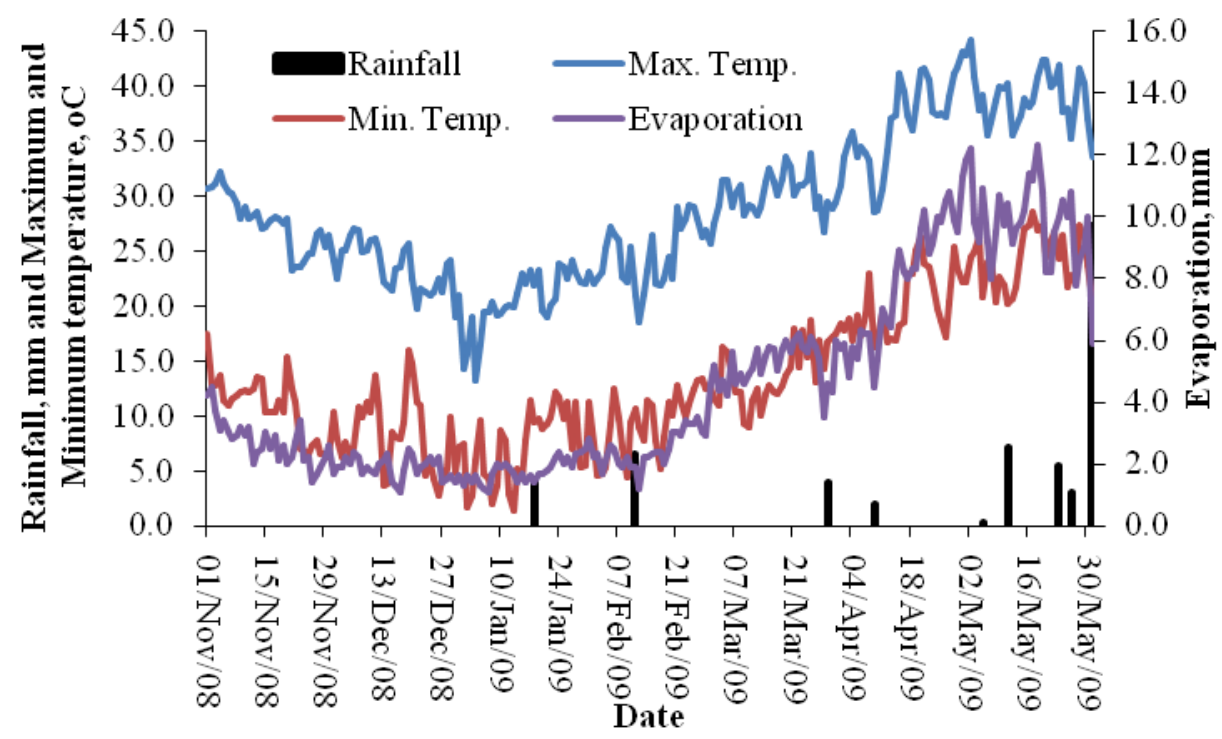

Fig. 1. Meteorological data during experimentation a) 2007-08 and b) 2008-09.

model

\section{RESULTS AND DISCUSSION}

Spatial and temporal distribution of water in the soil: Spatial distribution of water is described with the data collected in the mid crop season. To find out, the temporal variation in the water after irrigation, soil samples were taken before irrigation, 4, 24, 48, 52 and $72 \mathrm{~h}$ after irrigation for $I_{1}$ and for $I_{2}$, samples were collected before irrigation, 4, 24, 48, 72, 96, 100 and $120 \mathrm{~h}$ after irrigation.

Initial moisture content in the soil before irrigation varied from 17 to $22 \%$ in various soil layers. In all the treatments, water applied through drip irrigation was more than required rate. This more application of water was necessary for the proper establishment of the crop. After the establishment of the onion, irrigation was applied according to calculated amount per treatment. Average water distribution pattern under irrigation treatments, $I_{1}$ and $I_{2}$, are shown in Fig. 5 and 6.

The soil water content under $\mathrm{I}_{1}$ was relatively higher in upper profiles and near the emitters. Water content in all soil layers decreased as the distance from emitter increased in the horizontal direction. Similar results were reported by Mishra (2001), Rajput and Patel 


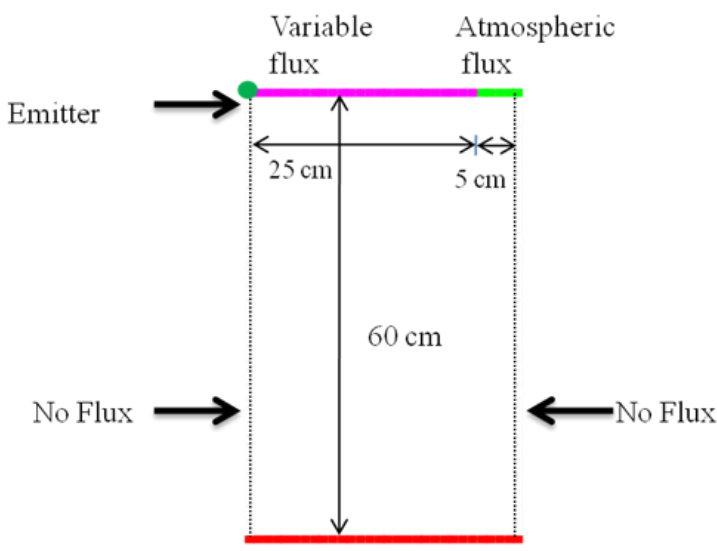

Free drainage

Fig. 2. Conceptual diagram of simulated area.

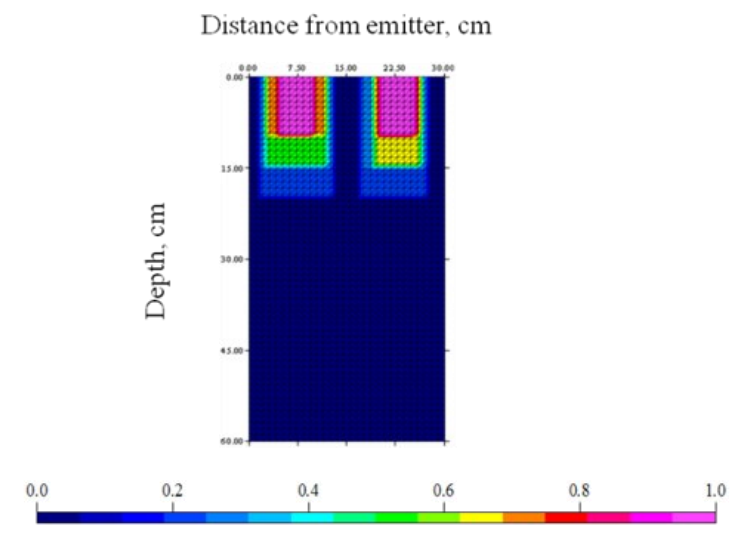

Fig. 4. Relative root distribution of Onion in Soil.

(2006). The similar trend was observed under $I_{2}$. But compared to $\mathrm{I}_{1}$, more soil water content was observed in lower soil layers under $\mathrm{I}_{2}$. This may be because of more quantity of irrigation water applied during single irrigation duration.

The analysis of Fig. 5 (a) revealed that simulated and observed water contents under $\mathrm{I}_{1}$ follow a similar trend without much difference. The values of simulated and observed soil water content after $24 \mathrm{~h}$ varied from 23 -

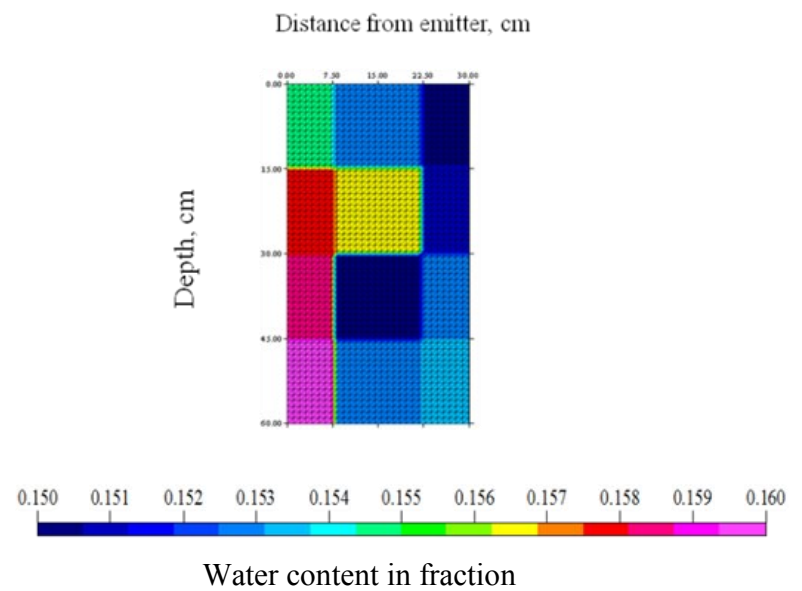

Fig. 3. Initial conditions of water content in Soil.

$26 \%$ and $19-22 \%$, respectively. The soil water content increases $4 \mathrm{~h}$ after the next irrigation and simulated values followed the similar trend. Fig. 5 (b and c) showed the horizontal as well as vertical water content variation. Similar trend was observed $15 \mathrm{~cm}$ away from emitter and $22.5 \mathrm{~cm}$ away from emitter. In simulated and observed water content values, lowest moisture content was near the field capacity. A similar analysis was done for $\mathrm{I}_{2}$ irrigation treatment and is depicted in Fig. 6. Compared to $I_{1}$, more moisture content was observed at upper as well as lower layers at the emitter. Simulated values also showed the similar trend. The water content values are decreasing from emitter to away from emitter (Fig. 6). This indicates that the model is able to simulate the soil water content as there was not much difference between the observed and simulated values.

The coefficient of determination $\left(\mathrm{R}^{2}\right)$, mean absolute error (MAE) and root mean square error (RMSE) were determined as model performance parameters for $\mathrm{I}_{1}$ and $I_{2}$, which are given in Table 4 and 5 . The $R^{2}$ between the observed and simulated values varied from 0.65 to 0.99 . The MAE and RMSE were also estimated to examine the predictability of the model. MAE and RMSE values varied from 0.018 to 0.030 .

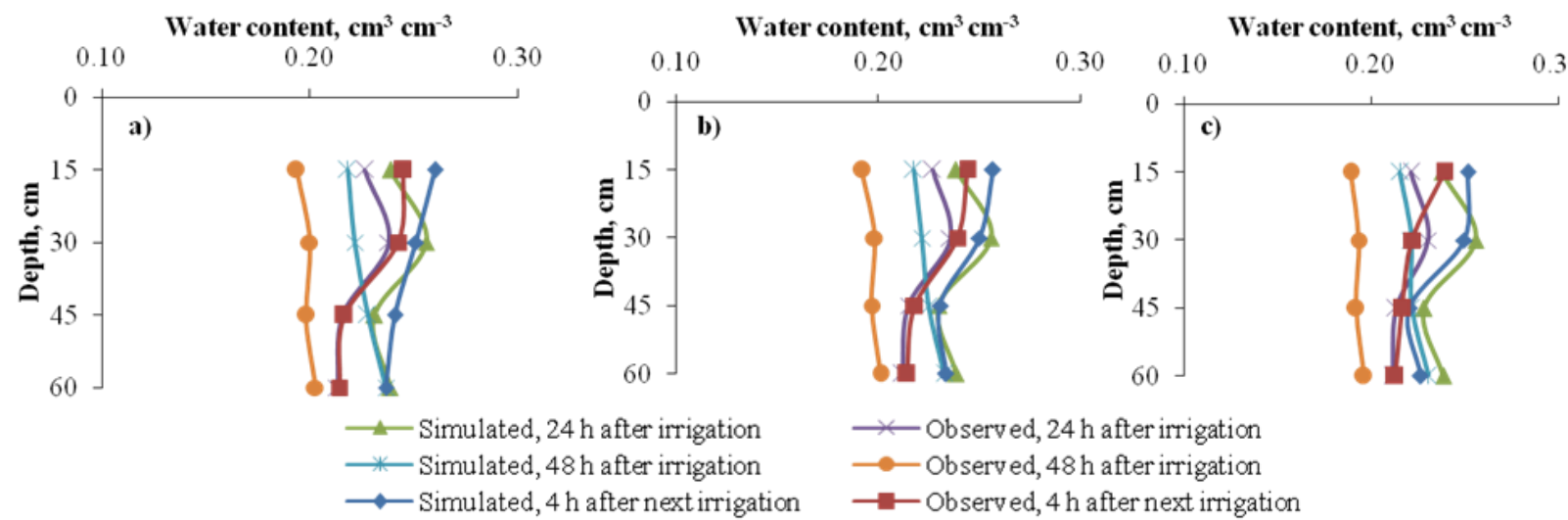

Fig. 5. Simulated and observed water content in $I_{1}($ a) at emitter (b) at $15 \mathrm{~cm}$ from emitter (c) at $22.5 \mathrm{~cm}$ from emitter. 
Sanjay T. Satpute and Man Singh / J. Appl. \& Nat. Sci. 9 (2): 720 - 729 (2017)

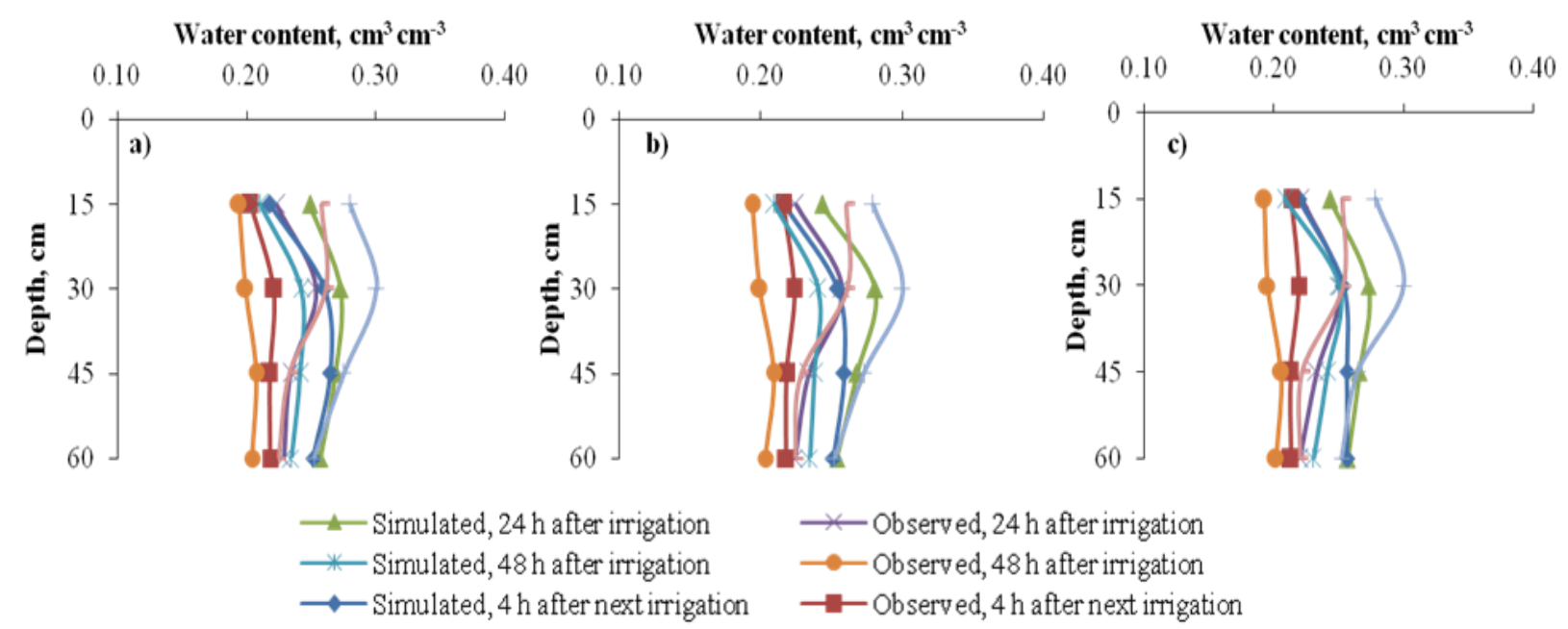

Fig. 6. Simulated and observed water content in $I_{2}($ a) at emitter (b) at $15 \mathrm{~cm}$ from emitter (c) at $22.5 \mathrm{~cm}$ from emitter.

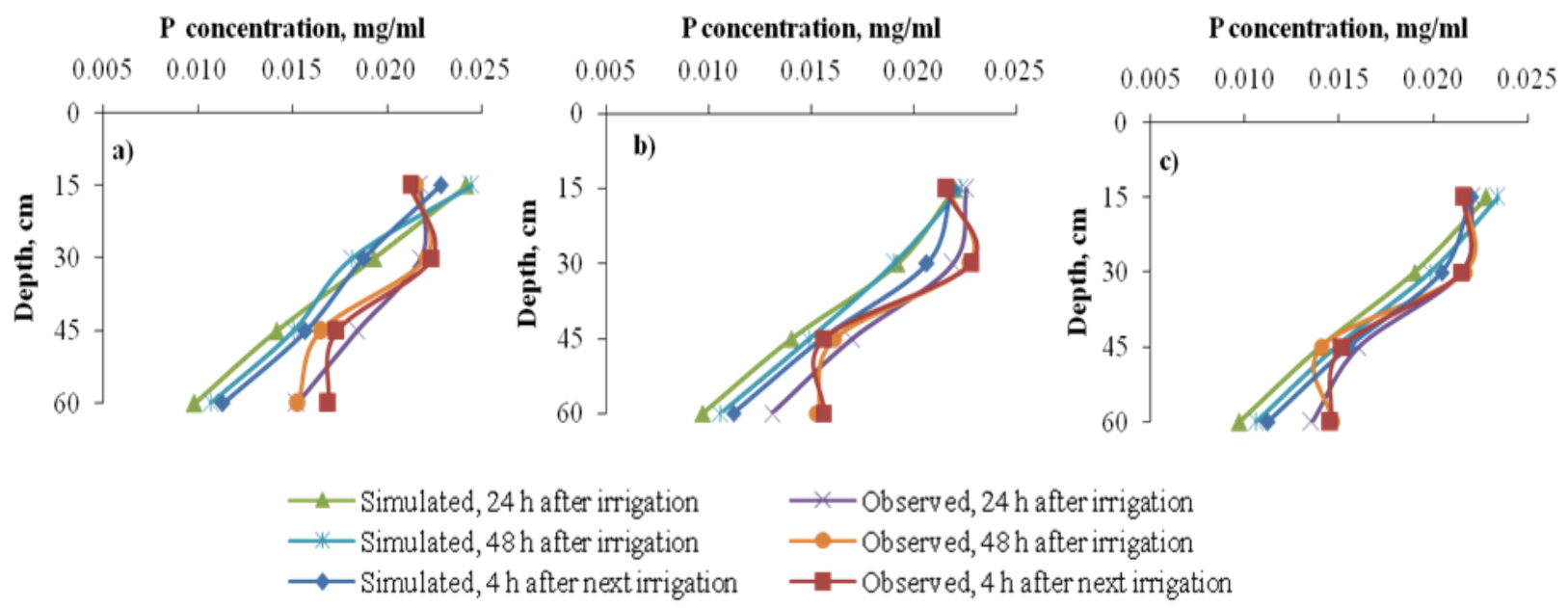

Fig. 7. Simulated and observed $P$ concentration in $I_{1}($ a) at emitter (b) at $15 \mathrm{~cm}$ from emitter (c) at $22.5 \mathrm{~cm}$ from emitter.

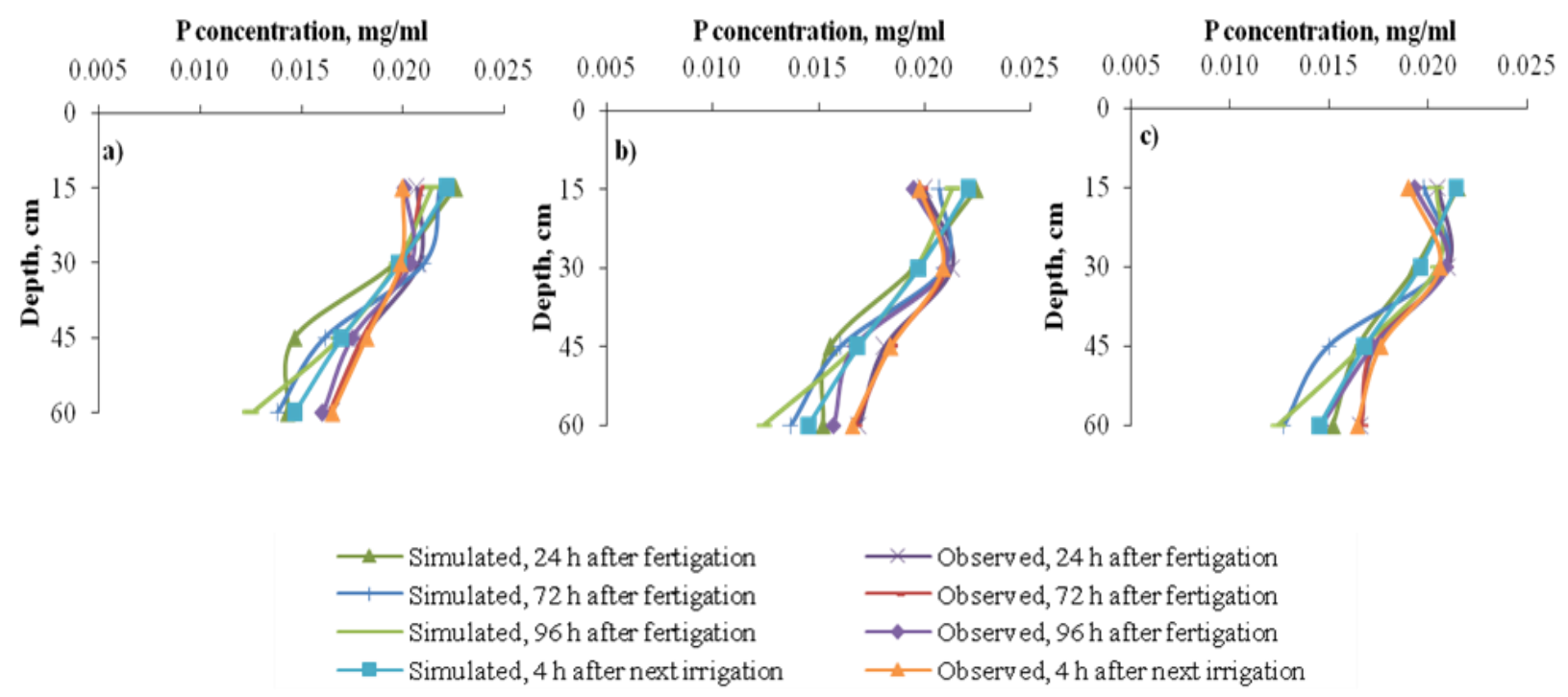

Fig. 8. Simulated and observed $P$ concentration in $I_{2}$ (a) at emitter (b) at $15 \mathrm{~cm}$ from emitter (c) at $22.5 \mathrm{~cm}$ from emitter. 

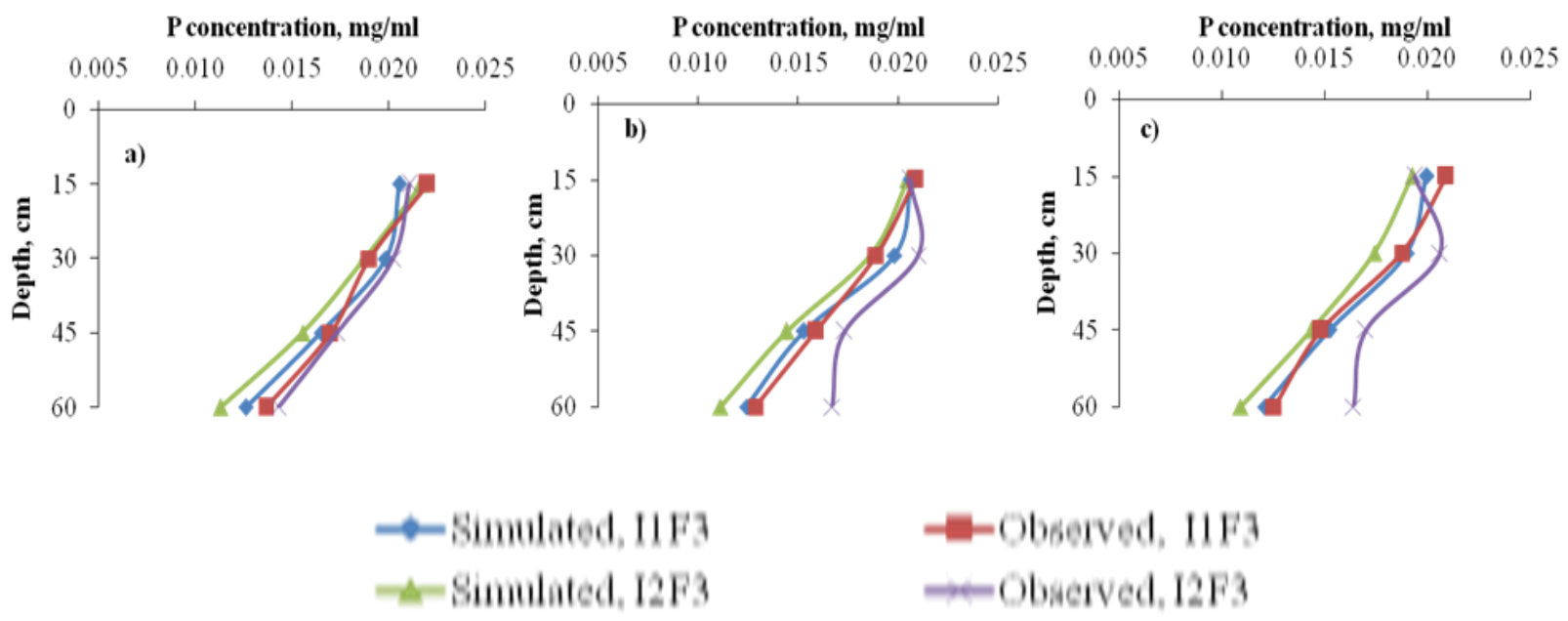

Fig. 9. Validation of P distribution (a) at emitter (b) at $15 \mathrm{~cm}$ from emitter (c) at $22.5 \mathrm{~cm}$ from emitter.

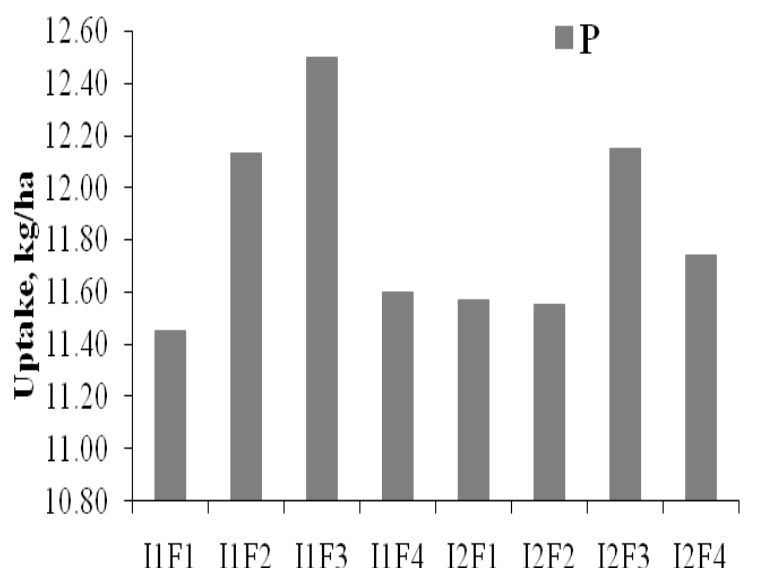

Treatment

Fig. 10. Uptake of phosphorus by onion plant under different treatments.

This indicated that HYDRUS-2D can be used to simulate water distribution with very good accuracy. These finding were in line of the results of Skaggs et al. (2004). For $\mathrm{I}_{2}$, coefficient of determination values varied from 0.65 to 0.88 . The MAE and RMSE values varied from 0.029 to 0.039 which was more than the values of MAE and RMSE under $I_{1}$. The higher $R^{2}$ values revealed the better correlation between the observed and simulated values for $\mathrm{I}_{1}$ and $\mathrm{I}_{2}$. It means that HYDRUS-2D can be used to simulate water distribution with better accuracy in $\mathrm{I}_{1}$ than $\mathrm{I}_{2}$.

Spatial and temporal distribution of phosphorus in the soil: Spatial distribution of nutrients has been described using the data collected during the crop season. The different fertigation strategies described in methodology were followed during fertigation. From the yield data of the onion, $F_{3}$ strategy was found to be better than other strategies. So, $\mathrm{F}_{3}$ fertigation strategy was selected for describing the nutrient distribution and intensive sampling was done in $F_{3}$ in 2009 as compared to 2008. To find out the temporal variation in the nutrient distribution, soil samples were taken before fertigation, 4, 24, 48, 52 and $72 \mathrm{~h}$ after fertigation for $I_{1}$ and for $I_{2}$, samples were collected before fertigation, 4, 24, 48, 72, 96, 100 and $120 \mathrm{~h}$ after fertigation.

Phosphorus distribution: The phosphorus concentration under $F_{3}$ was higher in upper profiles but in $F_{1}, F_{2}$ and $\mathrm{F}_{4}$, P concentration was more at deeper layers (Figs. 7 and 8 ). Phosphorus is highly immobile but its mobility and availability increases with the moisture content (Ben-Gal and Dudley, 2003; Fanish and Muthukrishnan, 2013). Continuous wetting helps to move the phosphorus at deeper layers. Fertigation during second half of irrigation duration $\left(\mathrm{F}_{3}\right)$ helps to keep more $\mathrm{P}$ concentration at upper layers which can be available in the active root zone of the onion.

The model was used to predict the $\mathrm{P}$ concentration under $F_{3}$ treatment. Figs. 7 and 8 showed the observed and simulated $\mathrm{P}$ concentration at various depths and at various time intervals after the fertigation duration. Results indicated that simulated and observed $\mathrm{P}$ concentration followed a similar trend. The observed $\mathrm{P}$ concentration decreased with elapsed time and with application of irrigation water. In case of $\mathrm{P}$ concentration, simulated values were less than observed values which means that model is under predicting the $\mathrm{P}$ movement. The simulated and observed $\mathrm{P}$ concentrations at the emitter after $24 \mathrm{~h}$ of the fertigation were 0.0242 and $0.0217 \mathrm{mg} / \mathrm{ml}$ in the first layer and it was 0.0240 and $0.0215 \mathrm{mg} / \mathrm{ml}$ in the same layer in $48 \mathrm{~h}$ after fertigation. Simulated and observed P concentration decreased away from the emitter. Similar trend was observed for all the layers. After next irrigation, $\mathrm{P}$ 
concentration showed decreasing trend in the upper layers while the concentration in lower layers was increased. A similar trend was observed under four day irrigation interval $\left(\mathrm{I}_{2}\right)$ and presented in Fig. 8. The more $\mathrm{P}$ concentration was observed in lower layers under $\mathrm{I}_{2}$ due to the more amount of irrigation during the single irrigation event. That helps to travel $\mathrm{P}$ at lower layers.

To examine the predictability of the model on seasonal basis, simulations were carried out to predict the $\mathrm{P}$ distribution at the end of the crop season i.e. 135 days (Fig. 9). The coefficient of determination $\mathrm{R}^{2}$, mean absolute error (MAE) and root mean square error (RMSE) were determined to find out the closeness between observed and simulated values and the accuracy of the model under $I_{1}$ and $I_{2}$. Those are presented in Table 4 and 5 . The higher (0.72 to 0.99$)$ values of $\mathrm{R}^{2}$ indicated that simulated and observed values of $\mathrm{P}$ movement are highly correlated. MAE and RMSE values for $\mathrm{P}$ concentration varied from 0.0009 to 0.0039 . The lower values of MAE and RMSE indicating the high accuracy and effectiveness of the HYDRUS-2D model for simulating P movement. The performance parameters revealed that the HYDRUS2D may be used for the simulation of $\mathrm{P}$ distribution under drip fertigation. The similarresults of HYDRUS2Dwere reported by Li et al. (2005) and Ajdary et al. (2007).

Nutrient uptake by the plant: The onion plant samples collected at the harvest were analysed in the laboratory to determine $\mathrm{P}$ uptake by the plant. Irrespective of the irrigation interval, the highest plant uptake of $\mathrm{P}$ $(12.50 \mathrm{~kg} / \mathrm{ha})$ was observed in $\mathrm{F}_{3} . \mathrm{F}_{3}$ retained most of the nutrients in the upper profile making them easily available for the plant. The combined effect of fertigation and irrigation strategies showed in Fig. 10 which revealed that the highest $\mathrm{P}$ uptake was found under $\mathrm{I}_{1} \mathrm{~F}_{3}$. The similar results were reported by EL-Desuki et al., 2006; Jha et al., 2000. The statistical analysis indicated that there was non-significant difference between the uptake of nutrients under different fertigation strategies. It can therefore be assumed that fertigation strategy did not have any impact on the uptake of the nutrients by plant.

\section{Conclusion}

Higher concentrations of $\mathrm{P}$ were observed at upper layers under the fertigation during the second half of irrigation duration. HYDRUS-2D model was used for the prediction of $\mathrm{P}$ concentration in different fertigation strategies and the results revealed that observed values were satisfactorily predicted. Calibration and validation results showed that HYDRUS-2D can be used for simulation of water and $\mathrm{P}$ distribution and leaching from the onion field (Cote et al., 2003; Hanson et al., 2006). The $\mathrm{R}^{2}$, MAE and RMSE values indicated show better matching between observed and simulated results. The $\mathrm{R}^{2}$ values ranged from 0.72 to 0.99 which indicated that observed and predicted values were highly correlated. The MAE and RMSE for water and nutrient distribution ranged between 0.0009 to 0.0039 . The lower values of MAE and RMSE showed the accuracy and effectiveness of the HYDRUS-2D model. Results revealed that $\mathrm{P}$ uptake by plant was maximum in case of $\mathrm{I}_{1} \mathrm{~F}_{3}$ treatment but the differences among the other treatments were non-significant. From the water and nutrient distribution information and under different treatments, it can be concluded that the HYDRUS-2D model can be used for the simulation of the water and nutrient distribution under different fertigation and irrigation scenarios. This will help to reduce the cost and time of performing the experiment on each soil type and for every discharge rate of the emitter.

\section{REFERENCES}

Ajdary, K., Singh, D. K., Singh, A. K. and Manoj Khanna. (2007). Modeling of nitrogen leaching from experimental onion field under drip fertigation. Agric. Water Manage., 89: $15-28$

Akbar, A. K., Yitayew, M. and Warrick, A. W. (1996). Field evaluation of water and solute distribution from point source. J. Irrig. Drain. Eng., 122(4): 221-227

Allen, R. G., Pereira, L. S., Raes, D. and Smith, M. (1998). Crop evapotranspiration. Guidelines for computing crop water requirements. FAO Irrigation and Drainage Paper No. 56, FAO, Rome, Italy, p. 300

Ben-Gal, A. and Dudley, L. M. (2003). Phosphorus availability under continuous point source irrigation. Soil Sci. Soc. Am. J., 67: 1449-1456

Cote, C. M., Bristow, K. L., Charlesworth, P. B. and Cook, F. J. (2003). Analysis of soil wetting and solute transport in sub-surface trickle irrigation. Irrig. Sci., 22 (3-4): 143-156

Doltra, J. and Muñoz, P. (2010). Simulation of nitrogen leaching from a fertigated crop rotation in a Mediterranean climate using the EU-Rotate_N and Hydrus-2D models. Agric. Water Manage., 97(2): 277-285

EL-Desuki, M., Abdel-Mouty, M. M. and Ali, A. H. (2006). Response of onion plants to additional dose of potassium application. J. Applied Sci. Research., 2(9): 592-597

Fanish, S. A. and Muthukrishnan, P. (2013). Nutrient distribution under drip fertigation systems. World Journal of Agricultural Sciences, 9(3): 277-283

Feddes, R. A., Kowalik, P. J. and Zaradny, H. (1978). Simulation of field water use and crop yield. In: Simulation Monographs, Pudoc, Wageningen

Gardenas, A. I., Hopmans, J. W., Hanson, B. R. and Simunek, J. (2005). Two-dimensional modelling of nitrate leaching for various fertigation scenarios under micro-irrigation. Agric. Water Manage., 74(3): 219-242

Hanson, B.R., Simunek, J. and Hopmans, J. W. (2006). Evaluation of urea-ammonium-nitrate fertigation with drip irrigation using numerical modelling. Agric. Water Manage., 86: 102-113

Heinen, M. (2001). FUSSIM2: Brief description of simulation model and application to fertigation scenarios. Agronomy, 21: 285-296 
Hopmans, J. W. and Bristow, K. L. (2002). Current capabilities and future needs of root water and nutrient uptake modeling. Adv. Agron, 77: 104-175

Jha, A. K., Pal, N. and Singh, N. (2000). Phosphorus uptake and its utilization by onion varieties at different stages of growth. Indian J. Hort., 57(4): 347-350

Li, J., Zhang, J. and Rao, M. (2005). Modeling of water flow and nitrate transport under surface drip fertigation. Trans. ASAE., 48: 627-637

Mishra, P. (2001). Studies on Water and Potassium dynamics in soil under fertigation and furrow irrigation in Radish. M.Sc. Thesis, Division of Agricultural Engineering, IARI.

Mmolawa, K. and Or, D. (2000). Water and solute dynamics under a drip-irrigated crop: experiments and analytical model. Trans. Am. Soc. Agric. Eng., 43(6): 1597-1608

Narda, N. K. and Chawla, J. K. (2002). A simple nitrate sub-model for trickle fertigated potatoes. Irrig. Drain. $51,361-371$

Nash, J. E. and Sutcliffe, J. V. (1970). River flow forecasting through conceptual models part I- A discussion of principles. J. Hydrol., 10 (3): 282-290

Patel, N. and Rajput, T. B. S. (2000). Effect of fertigation on growth and yield of onion. In: Micro Irrigation, CBIP publication no. 282, Pp. 451-454

Patel, N. and Rajput, T. B. S. (2008). Dynamics and modeling of soil water under subsurface drip irrigated onion. Agric. Water Manage., 95: 1335-1349

Rajput, T. B. S.and Patel, N. (2006). Water and nitrate movement in drip-irrigated onion under fertigation and irrigation treatments. Agric. Water Manage., 79 (3): 293311

Simunek, J., Sejna, M. and van Genuchten, M. Th. (1999). The HYDRUS-2D software package for simulating the two-dimensional movement of water, heat and multiple solute in variably-saturated media. International Groundwater Modeling Centre, Colorado School of Mines Golden, Co 80401.

Simunek, J., Sejna, M. and van Genuchten,M. Th. (2006). The HYDRUS software package for simulating twoand three-dimensional movement of water, heat, and multiple solutes in variably-saturated media. In: User Manual, Version 1.0. PC Progress, Prague, Czech Republic.

Skaggs, T., Trout, T., Simunek, J. and Shouse, P. (2004). Comparison of HYDRUS-2D simulations of drip irrigation with experimental observations. J. Irrig. Drain. Eng., 130: 304-310

Van Genuchten, M. Th. (1980). A closed-form equation for predicting the hydraulic conductivity of unsaturated soils. Soil Sci. Soc. Am. J., 44: 892-898

Wang, Z., Li, J. and Li, Y. (2014). Simulation of nitrate leaching under varying drip system uniformities and precipitation patterns during the growing season of maize in the North China Plain. Agric. Water Manage., 142: $19-28$

Willmott, C. J. (1981). On the validation of the models. Physical Geography, 2: 184-194

Zur, B. (1996). Wetted soil volume as design objective in trickle irrigation. Irrig. Sci., 16: 101-105 